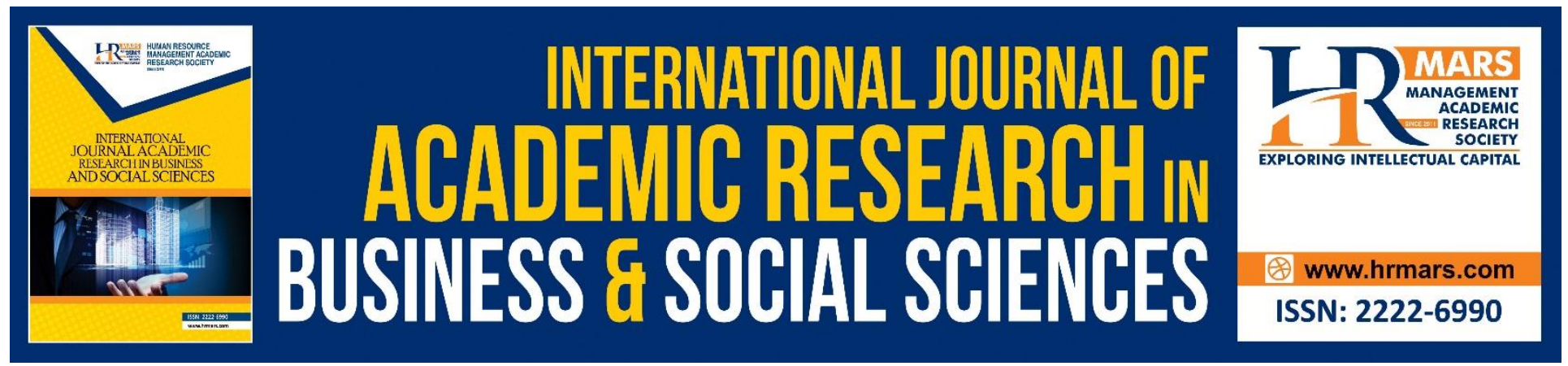

\title{
Intellectual Capital and Organizations Performance in Financial Industry in Malaysia
}

\section{Rashidah Kamarulzaman}

To Link this Article: http://dx.doi.org/10.6007/IJARBSS/v8-i11/5558

DOI: $10.6007 /$ IJARBSS/v8-i11/5558

Received: 15 Oct 2018, Revised: 24 Nov 2018, Accepted: 30 Nov 2018

Published Online: 08 Dec 2018

In-Text Citation: (Kamarulzaman, 2018)

To Cite this Article: Kamarulzaman, R. (2018). Intellectual Capital and Organizations Performance in Financial Industry in Malaysia. International Journal of Academic Research in Business and Socal Sciences, 8(11), 1939-1953.

Copyright: (C) 2018 The Author(s)

Published by Human Resource Management Academic Research Society (www.hrmars.com)

This article is published under the Creative Commons Attribution (CC BY 4.0) license. Anyone may reproduce, distribute, translate and create derivative works of this article (for both commercial and non-commercial purposes), subject to full attribution to the original publication and authors. The full terms of this license may be seen

at: http://creativecommons.org/licences/by/4.0/legalcode

Vol. 8, No. 11, 2018, Pg. 1939 - 1953

http://hrmars.com/index.php/pages/detail/IJARBSS

JOURNAL HOMEPAGE

Full Terms \& Conditions of access and use can be found at http://hrmars.com/index.php/pages/detail/publication-ethics 


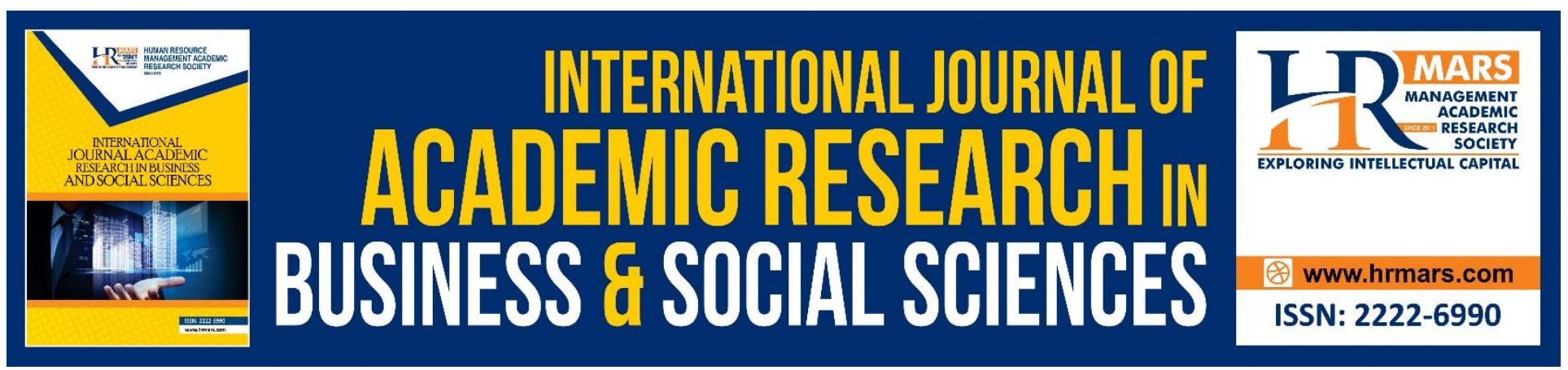

\title{
Intellectual Capital and Organizations Performance in Financial Industry in Malaysia
}

\author{
Rashidah Kamarulzaman \\ University College of Technology Sarawak, School of Business and Management, 868 Persiaran \\ Brooke 96000 Sibu, Sarawak, Malaysia
}

\begin{abstract}
As the economy has transformed globally into knowledge economy, many organizations have now changed their dependence on production asset to knowledge asset, which is also known as the intellectual capital. Effective utilization of these intangible resources is the driver for better performance for the organizations hence the issue of measurement is critical. Current measurement tend to focus more on the measurement of intellectual capital from the perspectives of 'traditional accounting' model which measure the past value creation rather than the utilization of the intellectual capital. This situation has inspired more empirical works in developing a more robust measurement of intellectual capital. This study measures the utilization of intellectual capital in the organizations using both the published financial data as well as the survey distributed to the senior management team. The sample size selection is the organizations within the Malaysian financial industry that comprises four major groups which are the insurance, banking and finance, capital market and development financial institutions. The objectives for the study is twofold; to examine the relationship between the components that make up intellectual capital and performance of the organizations and secondly to measure those components using the Value Added Intellectual Capital (VAIC) method and a new method of Utilized Intellectual Capital (UIC). The findings show that UIC measurement is more robust compared to VAIC. Both structural capital and transactional leadership components are significant towards the organizations' performance and culture was found to act as a mediator in the model.
\end{abstract}

Keywords: Intellectual Capital, Organizational Performance

\section{Introduction}

Intellectual capital is considered as the crucial assets in competing in the knowledge-based economy. Long gone the era where the organizations are relying on the production based output. Organizations have changed from relying on production workers to knowledge workers. The intellectual words itself derived from the word knowledge. Thus, to sustain the competitive advantage and to survive in the new economy, organizations need to transform on their reliance to knowledge from production. High 
dependency on knowledge means that the daily operation of the organizations revolving on the utilizing of knowledge in all aspect of capitals.

Intellectual Capital is developed or created within the organization through the utilization of the resources for example: skilled staff, product diversity and professional relationships with the stakeholders (Zakery, Afrazeh, 2015). Effective utilization of the intangible resources such as knowledge is the driver for better performance for the organization. The increase of useful knowledge as well as the knowledge application extensions is the essence of the Knowledge Economy. However, without proper utilization of this knowledge it will lead the organization to failure. Thus, it is important to measure the Intellectual Capital also from the utilization perspective instead of just depending on traditional accounting measures.

Organizations are relying on both tangible and intangible resources. With the current advancement of technology as well as the enhancement of a Knowledge Economy, more organizations are giving more attention towards the utilization of intangible resources. Decades ago, organizations are only acknowledging patents, copyrights and goodwill in their financial statements. In terms of human capital dependency, the organizations utilize the skills, expertise and experience of the human capital in creating the wealth and value to the organizations. Human capital manages and compliment other input in the organizations in order to achieve the organizations' objectives. Through the utilization of their knowledge, the human capital transforms the other capitals into the intended output.

Structural capital are those capital that shaped the organizations. Structural capital consist of the guidelines, technology, business process and models, and rules which managed carefully lead the organization into superior performance. Structural capital binds together all the other capitals to the organizations through the philosophy, mission and vision of the organizations. Relational capital is whereby the organizations is fully utilizing the external and internal relationship of the organizations that can contribute to the performance be it financially or non-financially. Finally, the customer capital is whereby the organizations utilize the brand name, intellectual property and trademark that will increase the value of the organizations. The value of the customer capital utilization to the organizations is translated in the customers' loyalty towards the organizations.

Intellectual capital needs to be utilized and managed effectively in order for the organization to improve the performance. All the sub-capitals (components) are interrelated and organizations must have the ability to transform these sub-capitals to benefits them. Numerous studies found that intellectual capital improves the performance of the organizations (Andreva, Garanina, 2017; Cerne, Etinger, 2016; Garg, 2016; Irsyahma, Nikmah, 2016; Inkinen, Kianto, Vanhala, Ritala, 2017). The study of the relationship between intellectual capital and performance has been conducted in major disciplines such as accounting, management, economics, information technology, sociology, psychology and education (Bontis, 2001) and in both the developed and non-developed countries.

Even though Intellectual Capital has been recognized as the organizations' value driver and has a significant relationship with performance; the issue of measuring Intellectual Capital is still largely debatable. Various attempts and approaches on the measuring of Intellectual Capital been made by companies and researchers. With the limitation of traditional accounting in measuring Intellectual Capital, new approaches are used to lead the way.

Due to the importance of the intellectual capital to the organizations' performance, this study examines the relationship between the intellectual capital components utilization and the 
contributions toward the organization performance in the financial industry. In examining the components, the study use two approaches of measuring the intellectual capital utilization.

Reasons for conducting this study are due to the nature of the industry itself. The nature of the financial sector is highly knowledge intensive sector that relies on the knowledge worker and as the financial sector falls in the services industry it is also a high relationship-rich industry. The financial sector also relies on the technology for their survival in the industry. Financial industry's revenues and performance is judged by the relationship with their customers. Innovation on the product development and dependability on quality, better and faster service is in question. According to Goh (2005), although physical capital is essential for banks to operate, it is the intellectual capital that determines the quality of services provided to customers.

It is utmost important now for the financial sector in Malaysia to transform their organization dependency on the physical capital to knowledge capital due to the current competitive environment. The financial organizations must strategize their intellectual capital utilization wisely and effectively. This study is to measure the utilization of the intellectual capital in the Malaysian financial sector which covers the insurance, banking and finance of both Islamic and conventional, capital market and development financial institutions (DFI). The study has practical significance to the country as a whole and to the financial sector in particular.

In measuring the intellectual capital, this study will use the current measurement approach, which is the Value Added Intellectual Capital (Pulic, 1998; 2003; 2004) and newly develop approach, which is the Utilized Intellectual Capital (UIC). The reason for adopting the current approach of VAIC is to examine the robustness of the approach and to compare with the findings of the UIC approach. Based from the two approaches, the author expects to find the main sub-capitals that contribute to the performance of the organizations. The newly develop UIC approach is using the sub-capitals in VAIC and two additional sub-capitals which are customer capital and leadership style. Additionally, culture will be used to be the mediator to the study.

In summary, the study strives to answer the following research objectives:

1. Examine the relationship between the intellectual capital components and organizations' performance using VAIC approach.

2. Develop a new model using the intellectual capital utilization in order to examine the relationship between the intellectual capital components and the organizations' performance known as Utilized Intellectual Capital (UIC).

\section{Literature Review}

It is a challenge now globally for organizations to measure the intangible assets (hidden assets) at both within and outside the organization. Furthermore the current performance measurement system does not justify and provide the solution to the measurement problem. This is due to heavy reliance on the financial and physical resources component of the balance sheet and lacking the information that is related to measuring the performance of its intangible asset resources.

This is in accordance with the previous works of Svanadze and Kowalewska (2015), Macerinskiene and Aleknaviciute (2015), Kamath (2015), Britto, Monetti and Lima Jr (2014) that mentioned although the intangible asset or Intellectual Capital is recognized as a vital corporate asset in generating 
sustainable competitive advantage, there are problems in measuring Intellectual Capital. Existing studies of Intellectual Capital have been focusing more on the measurement from the perspectives of the "accounting model" instead of focusing on the utilization of the Intellectual Capital. This is done through measuring Intellectual Capital using the publicly available financial reports of the organization.

Among the known approaches in measuring the intellectual capital are the Value Added Intellectual Capital (VAIC) (Pulic, 1998; 2003; Firer, Williams, 2003; Chen, Cheng, Hwang, 2005; Joshi, Cahill, Sidhu, Kansal, 2013; Mondal, Ghosh, 2012; Yalama, 2013; Ozkan, Cakan, Kayacan, 2016), the Balance Scorecard (Kaplan, Norton, 1996), the Skandia Navigator (Edvinsson, 1997; Marr, Schiuma, Neely (2004) and the Disclosure Index. However, some of these approaches were criticized by the scholars. The critiques on VAIC due to few reasons. Firstly, VAIC is measured through historical financial statements, suggesting that the coefficients are measured on the value created in the past and not on potential value creation in the future (Janosević, Dzenopoljac, Bontis, 2013). Secondly, according to Janosevic et al (2013) the model has the inability to integrate possible synergies of various Intellectual Capital components. Thus, it is not possible to measure individual components' contribution towards an organization's performance. Thirdly, VAIC does not measure the intellectual capital rather it is just measuring the value created by human capital (lazzolino, Laise, 2013). Finally, the VAIC measurement approach does not represent the actual utilization of the intellectual capital as it using the proxies indicator from the financial statement.

The other method of measurement is the Balance Scorecard that is using both financial and nonfinancial measures. The method was critique due to its inability to measure the utilization of the intellectual capital. The approach is designed to assist organizations to implant more balanced and strategic performance measurement and management systems.

The next method, which incorporates both financial and non-financial measure is the Skandia Navigator. The critique for the model is that it only provides timely snapshots rather than dynamic flows of Intellectual Capital as it relies heavily on the balance sheet approach (Roos, Roos, Edvinsson, Dragonetti, 1997). Secondly, the indicators list for the Skandia Navigator measure are too many for the users to understand what is being measured as well as the difficulty is determining the cause and effect from the model (Andriessen, 2004).

The scholars also have several critiques on the limitation of the Disclosure Index approach. Firstly according to Brennan and Connell (2000) intellectual capital information is mostly qualitative in nature and this affects comparability. Secondly is the non-standardization used in disclosing the intellectual capital disclosure index (Bukh, Nielsen. Gormsen, Mouritsen, 2005; Guthrie, Petty, Yongyanoch, Ricerri (2004). Thirdly, due to the source of information used is generally not audited and verified by an independent party. Finally, organizations choose not to disclose intellectual capital information due to the fear of losing the strategic advantage.

It is very crucial for the organizations to measure the utilization of the intellectual capital in order to ensure that they invest in the right resources. The decisions of investing in the right resources ensure the organizations sustainability and stability. This is in accordance with the theory of Resource-Based View (Spender, 1996) that states the importance to identify and examine how an organization's resources can be acquired, protected and valuated and how it is being controlled and utilized. 
Therefore, this study contributes to the development of an improved model for measuring the Intellectual Capital by assessing the utilization of the components of Intellectual Capital. The improved model will be compared to the most used measurement approach, which is the VAIC. This study uses both the measured Intellectual Capital from the published reports as well as the perceived Intellectual Capital from the perspectives of top management from financial institutions.

\section{Methodology}

Sample Selection

The sample for this study is all the organizations in the financial industry comprising of the four groups which are the insurance companies, banking and financial institutions, capital market institutions and development financial institutions (DFI) for the period of five years from 2008 to 2013. The primary sources of the data is through the questionnaires sent to the senior management team and secondary data sources are from the published materials from the websites. Based from the information from Bank Negara Malaysia and Malaysian International Islamic Finance Centre (MIFC) the size of the sample is a total of 122 organizations.

Measurement of Value Added Intellectual Capital (VAIC)

Value Added Intellectual Coefficients (VAIC) is a very important and consistent approach. VAIC is a component of Human Capital Efficiency (HCE), Structural Capital Efficiency (SCE) and Capital Employed Efficiency (CEE) which is develop by Pulic (2004). Value Added (VA) is calculated as the difference between outputs and inputs. The basic definition is as follows: VA = OUT - IN

There are four steps for calculating Value Added Intellectual Capital for the regression analysis (Chan, 2009; Shiu, 2006; Kujansivu, Lönnqvist, 2007). The steps are as per follows:

\section{First Step}

Company's value added

$\mathrm{VA}=$ Output - Input

Where,

$\mathrm{VA}=$ Value added

Output = Total Income

Input = Cost of buying materials, components and services

Another expression of Value Added

$\mathrm{VA}=\mathrm{R}+\mathrm{DD}+\mathrm{T}+\mathrm{EC}+\mathrm{D}+\mathrm{A}$

Where,

$\mathrm{R}=$ Retained Earnings

DD = Dividend

$\mathrm{T}=$ Taxes

$\mathrm{EC}=$ Total Employee Expenses/Investment

$D+A=$ Depreciation and Amortisation

$R+D D=$ Net Income After Tax (Chen, Cheng, Hwang, 2005; Feltham, Ohlson, 1999)

$\mathrm{R}+\mathrm{DD}+\mathrm{T}=$ Operating Profit (Pulic, 2004; Kujansivu, Lönnqvist, 2007)

Therefore,

$\mathrm{VA}=\mathrm{OP}+\mathrm{EC}+\mathrm{D}+\mathrm{A}$

Where, 
INTERNATIONAL JOURNAL OF ACADEMIC RESEARCH IN BUSINESS AND SOCIAL SCIENCES

Vol. 8, No. 11, Nov, 2018, E-ISSN: 2222-6990 @ 2018 HRMARS

$\mathrm{OP}=$ Operating Profit

$\mathrm{EC}=$ Total Employee Expenses/Investment

$D+A=$ Depreciation and Amortisation

II. Second Step

Human Capital Efficiency (HCE) is the investment on human capital in bringing value creation. HCE is an indicator of value added Human Capital and the expression for HCE is

HCE $=$ VA/HC

Where,

$\mathrm{VA}=$ Value Added

$\mathrm{HC}=$ Total payroll

III. Third Step

The share of structural capital in total value creation reflects structural capital efficiency (SCE). SCE is an indicator of value added Structural Capital and the expression for SCE is

SCE $=$ SC/VA

Where,

$\mathrm{SC}=\mathrm{VA}-\mathrm{HC}$

Where,

SC $=$ Structural Capital

$\mathrm{VA}=$ Value Added

$\mathrm{HC}=$ Total Payroll

IV. Fourth Step

Relational Employed Efficiency (CEE) is needed to create value both financially and physically. CEE is an indicator of value added Relational Employed and the expression is

CEE $=$ VA/CE

Where,

$\mathrm{VA}=$ Value Added

$C E=$ Book value of the net assets of the firm

Developing the New Model of Utilized Intellectual Capital (UIC)

UIC will be measured through both data; the survey collected from the senior management team of the financial institutions and the data collected from the published financial statement from the organizations' website. The variables for the UIC is as per Table 1. 
INTERNATIONAL JOURNAL OF ACADEMIC RESEARCH IN BUSINESS AND SOCIAL SCIENCES

Vol. 8, No. 11, Nov, 2018, E-ISSN: 2222-6990 @ 2018 HRMARS

Table 1: Variables for Utilized Intellectual Capital

\begin{tabular}{|c|c|c|c|c|}
\hline Variable & Constructs & $\begin{array}{l}\text { Indicators } \\
\text { /Items }\end{array}$ & $\begin{array}{l}\text { Items } \\
\text { Source }\end{array}$ & Reference \\
\hline Independent & $\begin{array}{l}\text { UIC: } \\
\text { Human } \\
\text { Capital, } \\
\text { Structural } \\
\text { Capital, } \\
\text { Relational } \\
\text { Capital, } \\
\text { Leadership } \\
\text { style }\end{array}$ & 59 & Primary & $\begin{array}{l}\text { Nazari } \\
\text { (2010), } \\
\text { Oulette } \\
\text { (2007), } \\
\text { Reed, } \\
\text { (2000), } \\
\text { Santoso } \\
\text { (2011), } \\
\text { Avolio and } \\
\text { Bass (2002) }\end{array}$ \\
\hline Dependent & $\begin{array}{l}\text { Performance: } \\
\text { Financial } \\
\text { Non-Financial }\end{array}$ & 8 & $\begin{array}{l}\text { Primary and } \\
\text { secondary }\end{array}$ & \\
\hline Mediating & $\begin{array}{l}\text { Organization } \\
\text { culture }\end{array}$ & 7 & Primary & $\begin{array}{l}\text { Denison } \\
(1990)\end{array}$ \\
\hline Control & $\begin{array}{l}\text { Organisation } \\
\text { size } \\
\text { Organisation } \\
\text { age }\end{array}$ & 2 & Secondary & \\
\hline Demographic & $\begin{array}{l}\text { Individual } \\
\text { Organisation }\end{array}$ & $\begin{array}{l}8 \\
3\end{array}$ & Primary & \\
\hline
\end{tabular}

In summary, both of the VAIC and UIC data will be analysed together using the SmartPLS 2 software tool.

\section{Results}

Both of the VAIC and UIC approaches is based on the partial least squares (PLS) method. SmartPLS 2 is a software tool that was used to assess the measurement and structural model. PLS was chosen as it works efficiently with the small sample sizes and the complex model (Hair et al., 2014). The research model was assessed using a two-step approach. First, the measurement model was analysed following the structural model analysis. Hair et al. (2014) state that the assessment of reflective outer models involves determining indicator reliability (squared standardized outer loadings), internal consistency reliability (composite reliability), convergent validity (average variance extracted, $\mathrm{AVE}$ ), and discriminant validity (Fornell-Larcker criterion, cross-loadings). The convergent validity of each construct is achieved as the item loadings for each construct are above the threshold of 0.700 .

Verification of the indicators reliability was obtained by calculating Cronbach's Alpha coefficient (CA), Composite reliability (CR) and the Average Variance Extracted (AVE) for the reflective 
constructs. Human Capital, Relational Capital, Structural Capital, Customer Capital, Leadership Style, Culture and Organization Performance all exhibit sufficient reliability given that the calculated values exceed the threshold ( $C A>0.700, C R>0.700, A V E>0.500)$. To confirm the discriminant validity among constructs (Fornell-Lacker criterion) the AVE square root must be superior to the correlation between constructs.

In summarising the measurement model, both the reliability and validity tests were satisfactorily conducted on both reflective and formative measurements. As the measurement model was reliable and valid, this can be used to estimate parameters in the second part, which was the structural model of PLS. Figure 1 will explain on the structural model result of the study on both model the VAIC and UIC.

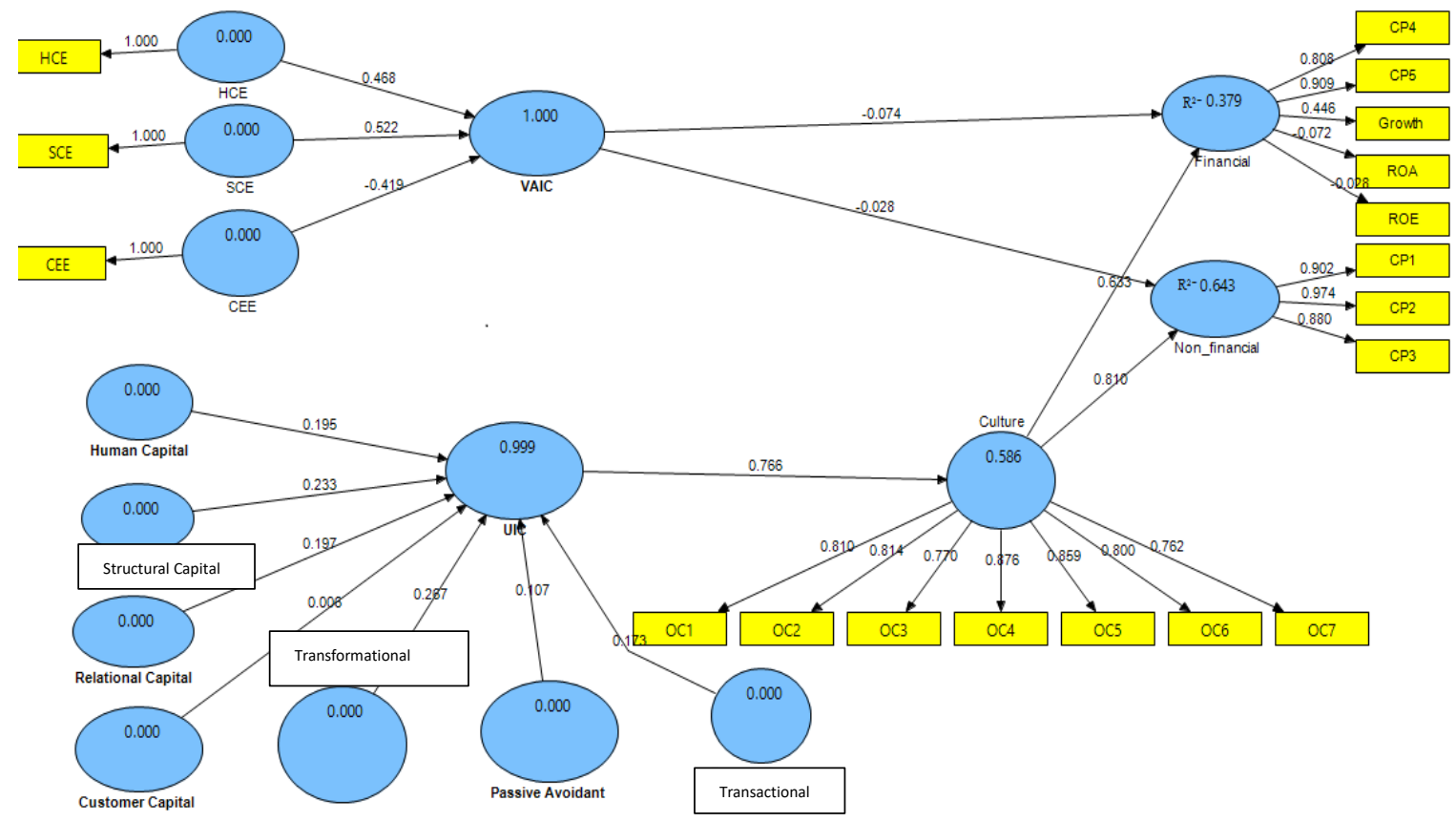

Figure 1: Structural model result

The $\mathrm{R}^{2}$ of structural model for both model is $38 \%$ on financial while $64 \%$ on non-financial. This can be summarized that, measured on single model VAIC show a low $R^{2}$ value but if it combined with the other model than the $R^{2}$ value increase substantially. Due to this, the evaluation for structural measurement model will only concentrate on the second model, which is the newly proposed model, the UIC.

Based on the above structural model, the VAIC model is not related with performance while the UIC model is significantly related to performance. Culture mediates the relationship between UIC and performance. In the first model of VAIC (Pulic, 1998) three variables were used to measure the Intellectual Capital and examine the relationship of its components i.e. Human Capital Efficiency, Structural Capital Efficiency and Capital Employed Efficiency with organisation performance. Based on the PLS analysis, only one relationship was supported which was between Structural Capital Employed and non-financial performance. Furthermore, the $\mathrm{R}^{2}$ value for the Value added 
INTERNATIONAL JOURNAL OF ACADEMIC RESEARCH IN BUSINESS AND SOCIAL SCIENCES Vol. 8, No. 11, Nov, 2018, E-ISSN: 2222-6990 @ 2018 HRMARS

Intellectual Capital is $6 \%$ on non-financial performance as opposed to $32 \%$ on financial performance, which explains that this model has low predictive power.

In the second model of Utilised Intellectual Capital, the variables for independent variables are Human Capital, Structural Capital, Relational Capital, Customer Capital and three different leadership styles i.e. Transformational, Transactional and Passive Avoidant. Based on the PLS analysis, the relationship between Structural Capital and Transactional Capital were supported. Table 2 shows the result for the hypothesis testing for this research. The followings are the hypothesis for objective 1 and 2 for the research:

Table 2: Hypothesis Result

\begin{tabular}{|c|c|c|c|c|c|}
\hline $\begin{array}{l}\text { Hypo } \\
\text { thesis }\end{array}$ & $\begin{array}{l}\text { Relation } \\
\text { ship }\end{array}$ & $\begin{array}{l}\text { Std } \\
\text { Beta }\end{array}$ & $\begin{array}{l}\text { Std } \\
\text { Error }\end{array}$ & t-value & Decision \\
\hline $\mathrm{H} 1$ & VAIC -> Performance & -0.0301 & 0.2291 & 0.1314 & $\begin{array}{l}\text { Not } \\
\text { Supported }\end{array}$ \\
\hline $\mathrm{H} 1 \mathrm{a}$ & CEE -> Financial & 0.5641 & 0.3355 & $1.6812^{* *}$ & Supported \\
\hline $\mathrm{H} 1 \mathrm{~b}$ & CEE -> Non-Financial & 0.411 & 0.1329 & 0.3094 & $\begin{array}{l}\text { Not } \\
\text { Supported }\end{array}$ \\
\hline $\mathrm{H} 1 \mathrm{c}$ & HCE -> Financial & 0.0395 & 0.2149 & 0.1838 & $\begin{array}{l}\text { Not } \\
\text { Supported }\end{array}$ \\
\hline $\mathrm{H} 1 \mathrm{~d}$ & HCE -> Non-Financial & 0.1126 & 0.1380 & 0.8163 & $\begin{array}{l}\text { Not } \\
\text { Supported }\end{array}$ \\
\hline H1e & SCE -> Financial & -0.0096 & 0.3502 & 0.0275 & $\begin{array}{l}\text { Not } \\
\text { Supported }\end{array}$ \\
\hline H1f & SCE -> Non-Financial & 0.2059 & 0.1401 & 1.4696 & $\begin{array}{l}\text { Not } \\
\text { Supported }\end{array}$ \\
\hline $\mathrm{H} 2$ & UIC -> Performance & 0.7920 & 0.1355 & $5.8443 * * *$ & Supported \\
\hline $\mathrm{H} 2 \mathrm{a}$ & Customer Capital -> Culture & 0.0015 & 0.1102 & 0.0133 & $\begin{array}{l}\text { Not } \\
\text { Supported }\end{array}$ \\
\hline $\mathrm{H} 2 \mathrm{~b}$ & Human Capital -> Culture & 0.0855 & 0.1993 & 0.4292 & $\begin{array}{l}\text { Not } \\
\text { Supported }\end{array}$ \\
\hline $\mathrm{H} 2 \mathrm{c}$ & Passive Avoidant -> Culture & -0.0683 & 0.1390 & 0.4911 & $\begin{array}{l}\text { Not } \\
\text { Supported }\end{array}$ \\
\hline $\mathrm{H} 2 \mathrm{~d}$ & Structural Capital -> Culture & 0.5669 & 0.1859 & $3.0498 * * *$ & Supported \\
\hline $\mathrm{H} 2 \mathrm{e}$ & Relational Capital -> Culture & -0.0926 & 0.2328 & 0.3976 & $\begin{array}{l}\text { Not } \\
\text { Supported }\end{array}$ \\
\hline$H 2 f$ & Transactional ->Culture & 0.3873 & 0.1932 & $2.0039 * *$ & Supported \\
\hline $\mathrm{H} 2 \mathrm{~g}$ & Transformational -> Culture & 0.0575 & 0.1715 & 0.3355 & $\begin{array}{l}\text { Not } \\
\text { Supported }\end{array}$ \\
\hline
\end{tabular}

$* * * p<0.01, * * p<0.05, * p<0.10$

In summary, the result showed that VAIC is not related to organizations' performance and UIC is significantly related to organizations' performance. Among the components of intellectual capital, both structural and transactional leadership style is significantly related to organizations' performance while the other components are not significant. 


\section{Discussion}

In order to achieve better organisation performance, it makes sense for organisations to invest strategically on the right capital that gives most impact to performance. In relation to measuring the right resources, the study develops a new measurement model that measures the utilisation of each of the component of Intellectual Capital.

The study recognises that the concept of Intellectual Capital comprises human capital, structural capital, relational capital, customer capital and leadership style. It is important for the organisation to know that the utilisation of the intangible resources is not the level of the resources itself. Through the old model of VAIC, the intangible resources are measured by the proxies of the published data instead of the perceived utilisation of the organisation's management. The findings from the study is inconsistent from the previous researches (Zehri, Abdelbaki, Bouabdellah, 2012; Muhamad, Ismail, 2009; Tan, Plowman, Hancock, 2007; Chen, Cheng, Hwang, 2005; Riahi-Belkaoui, 2003) whereby in this study it is found that VAIC does not relate to the organizations performance. Previous researchers found that VAIC is significantly related to organizations performance such as profitability, ROA and ROI. When the study introduced UIC, the results derived from the model were more comprehensive in the sense of the utilisation of Intellectual Capital.

The second finding from this study points to a new direction whereby structural capital is more vital among the components of Intellectual Capital. This departs from the current empirical study (Zakery, Afrazeh, 2015; Marzo, Scarpino (2016; Komnenic, Pokrajcic 2012), which suggests that human capital is more important towards the performance of the organisations and Yildiz, Meydan and Guner (2014) that states customer capital is important in Turkish banks compared to structural and human capital. This study indicates that structural capital which consists of framework, process, guidelines, technologies and systems are more vital in ensuring good performance rather than human capital which consists of skill, experience and qualification. Thus, an organisation is less affected by the people of the organisation but rather, by its strong systems. A strong organisation does not mean that it does not have high turnover but its sustainability and strength are derived from the strength in structural capital. Policy implications of the organisation are for the decision maker to put the investment in terms of the establishment of structural capital.

The final findings are concerning the leadership style. The findings of the study does not support that transformational leadership is vital in achieving better performance. The reason might be due to the style of Malaysian leaders and organisations. According to the respondents in the qualitative approach, Malaysian organisations are still not open to the transformational leadership style. Instead of coaching and mentoring, the leaders still opt for directing and authoritative style of leadership. Henceforth, this can be an avenue to study further on the leadership style and the organisation's performance from the perception of the employees. This will give better indication on the leadership style from the employees and a better comparison on two perceptions can be obtained.

\section{Conclusion}

In conclusion, the newly developed UIC method in measuring the utilization of intellectual capital can also be used as a performance metrics in the organisation. Individually, each organisation can measure the Intellectual Capital utilisation by adopting the same approach used by the researcher. A similar survey can be done and the analysis can be taken place in departments or if it is in a bigger 
scale, the whole organisation. Subsequently, this method can be used to assist the top management to understand and review their capital to improve the overall performance. Utilization is based on the questionnaires. Granted that this is based on the perception and arguably not a direct measure of utilization. This is at the time of the study the best way to measure utilization of the intellectual capital. Thus, the study supports that the method is robust and it provides a significant link between intellectual capital and performance, not provided by the other competing model of VAIC.

\section{Corresponding Author}

Saadiah Mohamad, Universiti Teknologi MARA, Arshad Ayub Graduate Business School, 40450 Shah Alam, Selangor, Malaysia.

\section{References}

Andreva, T., \& Garanina, T. (2017). Intellectual capital and its impact on the financial performance of Russian manufacturing companies. Foresight and STI Governance, 11(1), 31-40.

Andriessen, D. (2004). Making sense of intellectual capital: Designing a method for the valuation of intangibles, Elsevier Butterworth-Heinemann, Oxford.

Avolio, B. J., \& Bass, B. M. (2002). Manual for the multifactor leadership questionnaire (Form 5X). Redwood City, CA: Mindgarden.

Bontis, N. (2001). Assessing knowledge assets: A review of the models used to measure intellectual capital. International Journal of Management Reviews, 3(1), 41-60.

Brennan N., \& Connell, B. (2000). Intellectual capital: Current issues and policy implications. Journal of Intellectual Capital, 7(3), 206-240.

Britto, D. P., Monetti, E., \& Rocha Lima Jr. J. D., (2014). Intellectual capital in tangible intensive firms: the case of Brazilian real estate companies. Journal of Intellectual Capital, 15(2), 333-348.

Bukh, P., N., Nielsen, C., Gormsen, P., \& Mouritsen, J. (2005) Disclosure of information on intellectual capital in Danish IPO prospectuses. Accounting, Auditing \& Accountability Journal, 18(6), 713-732, https://doi.org/10.1108/09513570510627685

Cerne, K., \& Etinger, D. (2016). IT as a part of intellectual capital and its impact on the performance of the business entities. Croatian Operational Research Review, CRORR 7, 389-408.

Chan, K. (2009). Impact of intellectual capital on organisational performance: An empirical study of companies in the Hang Seng Index (Part 1). The Learning Organization, 16(1), 4-21.

Chen, M., Cheng, S. \& Hwang, Y. (2005). An empirical investigation of the relationship between intellectual capital and firms' market value and financial performance. Journal of Intellectual Capital, 6(2), 159-176.

Denison, D. R. (1990). Corporate culture and organizational effectiveness. New York: Wiley.

Edvinsson, L. (1997). Developing intellectual capital in Scandia. Long Range Planning, 30(3), 320331.

Feltham, G., \& Ohlson, J. (1999). Residual earnings valuation with risk and stochastic interest rates. The Accounting Review 74(2), 165-183.

Firer, S., \& Williams, S. M. (2003). Intellectual capital and traditional measures of corporate performance. Journal of Intellectual Capital, 4(3), 348-360. 
INTERNATIONAL JOURNAL OF ACADEMIC RESEARCH IN BUSINESS AND SOCIAL SCIENCES

Vol. 8, No. 11, Nov, 2018, E-ISSN: 2222-6990 @ 2018 HRMARS

Garg, S. (2016). Determinants of intellectual efficiency value: Empirical evidence of selected Indian banks. Vidyasagar University Journal of Commerce, 21, 36-51.

Goh, P. C. (2005). Intellectual capital performance of commercial banks in Malaysia. Journal of Intellectual Capital, 6(3), 385-396.

Guthrie, J., Petty, R., Yongvanoch, K., \& Ricerri, F. (2004). Using content analysis as a research method to inquire into intellectual capital reporting. Journal of Intellectual Capital, 5(2), 282293.

Hair, J. F., Hult, G. T. M., Ringle, C. M., \& Sarstedt, M. (2014). A primer on partial least squares structural equation modeling (PLS-SEM). Thousand Oaks.

Iazzolino, G., \& Laise, D. (2013). Value added intellectual coefficient (VAIC), Journal of Intellectual Capital, 14(4), $547-563$.

Inkinen, H., Kianto, A., Vanhala, M., \& Ritala, P. (2017) .Structure of intellectual capital - an international comparison. Accounting, Auditing \& Accountability Journal, 30(5), 1160-1183.

Irsyahma, A., \& Nikmah, N. (2016). Intellectual capital, firm value, and financial performance. AFEBI Accounting Review, Vol 1(1), 29-43.

Janosević, S., Dzenopoljac, V., \& Bontis, N. (2013). Intellectual capital and financial performance in Serbia. Knowledge and Process Management, 20(1), 1-11, http://dx.doi.org/10.1002/kpm.1404.

Joshi, M., Cahill, D., Sidhu, J., \& Kansal, M., (2013). Intellectual capital and financial performance: an evaluation of the Australian financial sector. Journal of Intellectual Capital, 14(2), 264-285.

Kamath, G. B. (2015). Impact of intellectual capital on financial performance and market evaluation of firms in India. International Letters of Social and Humanistic Sciences, 48, 107-122.

Kaplan, R. S., \& Norton, D. P. (1996). The balanced scorecard: Translating strategy into action, Harvard Business School Press.

Komnenic, B., \& Pokrajcic, D. (2012). Intellectual capital and corporate performance of MNCs in Serbia, Journal of Intellectual Capital, 13(1), 106-119.

Kujansivu, P., \& Lönnqvist, A. (2007). Investigating the value and efficiency of intellectual capital. Journal of Intellectual Capital, 8(2), 272-287.

Macerinskiene, I., \& Aleknaviciute, R. (2015). Comparative evaluation of national intellectual capital measurement models. Business: Theory and Practice, 16(1), 1-14. doi:10.3846/btp.2015.548.

Marr, B., Schiuma, G., \& Neely, A. (2004). Intellectual capital - defining key performance indicators for organizational knowledge assets. Business Process Management Journal, 10(5), 551-569, https://doi.org/10.1108/14637150410559225.

Marzo, G., \& Scarpino, E. (2016). Exploring intellectual capital management in SMEs. An in-depth Italian case study. Journal of Intellectual Capital, 17(1), 27-51.

Mondal, A., \& Ghosh, S. K. (2012). Intellectual capital and financial performance of Indian banks. Journal of Intellectual Capital, 13(4), 515-530.

Muhamad, N., \& Ismail, A. (2009). Intellectual capital efficiency and firm's performance: Study on Malaysian financial sectors. International Journal of Economics and Finance, 1(2), 206-212.

Nazari, J. A. (2010). An investigation of the relationship between the intellectual capital components and firm's financial performance. PhD thesis, Haskayne School Of Business Calgary, Alberta. 
INTERNATIONAL JOURNAL OF ACADEMIC RESEARCH IN BUSINESS AND SOCIAL SCIENCES

Vol. 8, No. 11, Nov, 2018, E-ISSN: 2222-6990 @ 2018 HRMARS

Oulette, R. P. (2007). Value creation in business incubation networks: the impact of innovation diffusion on intellectual capital development in start-up companies, PhD dissertation, University of Maryland, University College.

Ozkan, N., Cakan, S., \& Kayacan, M. (2017). Intellectual capital and financial performance: A study of the Turkish banking sector. Borsa Istanbul Review, 17(3), 190-198. http://dx.doi.org/10.1016/j.bir.2016.03.001.

Pulic, A. (2004). Intellectual capital-does it create or destroy value? Measuring Business Excellence, 8(1), 62-68.

Pulic, A. (1998). Measuring the performance of intellectual performance in knowledge economy. The 2nd McMaster World Congress on Measuring and Managing Intellectual Capital by the Austrian Team for Intellectual Potential.

Pulic, A. (2003). Intellectual capital efficiency on national and company level. International Business Efficiency Consulting, L.L.C.

Reed, K. K. (2000). The dynamics of intellectual capital, PhD dissertation, University of Connecticut.

Riahi-Belkaoui, A. (2003). Intellectual capital and firm performance of US multinational firms: A study of the resource-based and stakeholder views. Journal of Intellectual Capital, 4(2), 215226.

Roos, J., Roos, G., Edvinsson, L., \& Dragonetti, N. C. (1997). Intellectual capital: Navigating in the new business landscape. New York: Macmillan.

Santoso, E. (2011). Intellectual capital in Indonesia: The influence on financial performance of banking industry, PhD Dissertation, University of Phoenix.

Shiu, H. J. (2006). The application of the value added intellectual coefficient to measure corporate performance: evidence from technological firms. International Journal of Management, 23(2), 356-65.

Spender, J. C. (1996). Making knowledge the basis of a dynamic theory of the firm. Strategic Management Journal, 17, 45-62.

Svanadze, S., \& Kowalewska, M. (2015). The measurement of intellectual capital by VAIC method example of WIG20. Online Journal of Applied Knowledge Management, 3(2), 36-44.

Tan, H.P., Plowman, D., \& Hancock, P. (2007). Intellectual capital and financial returns of companies. Journal of Intellectual Capital, 8(1), 76-95.

Yalama, A. (2013). The relationship between intellectual capital and banking performance in Turkey: evidence from panel data. International Journal of Learning and Intellectual Capital, 10(1), 71-87.

Yildiz, S., Meydan, C., \& Guner, M. (2014). Measurement of intellectual capital through activity reports of companies. 2nd World Conference on Business, Economics and Management, WCBEM 2013.

Zakery, A., \& Afrazeh, A. (2015). Intellectual capital based performance improvement, study in insurance firms. Journal of Intellectual Capital, 16(3), 619-638.

Zehri, C., Abdelbaki, A., \& Bouabdellah, N. (2012). How intellectual capital affects a firm's performance? Australian Journal of Business and Management Research, 2(8), 24-31. 